\title{
PARAMETER BIOLOGI LOBSTER PASIR (Panulirus homarus) DI PERAIRAN TABANAN, BALI
}

\section{BIOLOGICAL PARAMETERS OF SCALLOPED SPINY LOBSTER (Panulirus homarus) IN TABANAN WATERS, BALI}

\author{
Duranta D. Kembaren, Pratiwi Lestari, dan Renny Ramadhani \\ Balai Penelitian Perikanan Laut, Jakarta \\ Teregistrasi I tanggal: 30 April 2014; Diterima setelah perbaikan tanggal: 07 April 2015; \\ Disetujui terbit tanggal: 09 April 2015 \\ e-mail :dd.kembaren@gmail.com
}

\begin{abstract}
ABSTRAK
Penelitian tentang aspek biologi lobster pasir (Panulirus homarus) di perairan Tabanan dilakukan pada periode Maret - Desember 2013. Penelitian ini bertujuan untuk mengetahui aspek biologi lobster pasir meliputi nisbah kelamin, sebaran panjang, kematangan kelamin, hubungan panjang berat dan faktor kondisi. Pengamatan dan pengukuran aspek biologi dilakukan di tempat pengumpul lobster dengan sistem sampling acak. Hasil penelitian menunjukkan bahwa nisbah kelamin lobster pasir berada pada keadaan seimbang. Hasil tangkapan lobster didominasi oleh lobster berusia muda dengan panjang karapas antara 47,5-52,5 mm. Pemijahan terjadi sepanjang tahun dan puncak musim pemijahan lobster pasir diduga terjadi pada bulan Oktober. Persamaan hubungan panjang dan berat lobster jantan adalah $\mathrm{W}=0,0021 \mathrm{~L}^{2,769}$ dan betina adalah $\mathrm{W}=0,0016 \mathrm{~L}^{2,841}$. Sifat pertumbuhan lobster pasir adalah allometrik negatif. Faktor kondisi relatif rendah pada saat musim pemijahan dan semakin menurun seiring dengan bertambah panjangnya ukuran karapas lobster. Rata-rata ukuran lobster yang tertangkap lebih kecil dari ukuran matang kelamin. Oleh karena itu disarankan untuk menetapkan ukuran minimum yang boleh ditangkap yaitu diatas $68,52 \mathrm{~mm}$.
\end{abstract}

KATA KUNCI: Parameter biologi, lobster pasir, perairan Tabanan

\begin{abstract}
Research about biological aspects of scalloped spiny lobster (Panulirus homarus) was conducted in Tabanan waters in the period of March to December 2013. The aims of this study was to know biological aspects, i.e. sex ratio, carapace length frequency, maturity, length-weight relationship and relative condition factor. Examination and measurement of biological aspects was done randomly in the lobster landing site. Distribution of carapace length frequency was tabulated and analysed according to the standard methods. The result showed that sex ratio of scalloped spiny lobster was equal and dominated by young lobsters with carapace length in the range of 47,5-52,5 mm. Spawning occurred all year around and reached it's peak on October. Length-weight relationship equation for male and female were $W=0,0021 \mathrm{~L}^{2,769}$ and $W=0,0016 \mathrm{~L}^{2,841}$, respectively. The growth characteristic of scalloped spiny lobster was allometric negative. Relative condition factor was lower on the spawning season and went down along with longer carapace length. Size at capture of scalloped spiny lobster was lower than size on maturity $(L c<S o M)$. Thus, it is recommended that minimum legal size should be applied to this fishery in the carapace length greater than $68,52 \mathrm{~mm}$.
\end{abstract}

KEYWORDS: Biological parameters, scalloped spiny lobster, Tabanan waters

\section{PENDAHULUAN}

Lobster pasir (Panulirus homarus) merupakan salah satu jenis lobster yang banyak ditemukan di periaran Indonesia, khususnya di perairan Samudera Hindia. Lobster ini digolongkan dalam kelompok lobster berduri (spiny lobster) yang di Indonesia dikenal dengan nama udang karang/udang barong karena pada umumnya banyak ditemukan di perairan karang. Udang karang atau lobster yang paling banyak di temukan di perairan Indonesia termasuk dalam famili Palinuridae dan genera Panulirus.
Menurut Subani (1981), di perairan Indonesia terdapat 4 - 7 jenis udang karang yang tersebar disepanjang perairan Samudera Hindia mulai dari perairan Aceh Barat sampai Nusa Tenggara. Jenis-jenis tersebut yaitu Panulirus ornatus, $P$. penicillatus, $P$. versicolor, $P$. longipes, $P$. homarus dan Scyllarides squammosus. Di perairan Aceh Barat terdapat 4 jenis lobster yang didominasi oleh jenis Panulirus homarus (Suman\&Subani, 1993), di perairan selatan Jawa Barat dan Selat Sunda terdapat 3-5 jenis lobster (Iriana, 1978 dalam Subani, 1981), di perairan Pangandaran, Jawa Barat dan perairan Bima, Nusa Tenggara Barat terdapat 4 jenis lobster yang diusahakan 
(Suman et al., 1994). Sementara itu di perairan selatan Yogyakarta terdapat 5 genera Panulirus (Aisyah \& Triwahyuni, 2010) dan di pantai selatan Bali ditemukan 7 jenis lobster, yang didominasi oleh jenis lobster pasir (Panulirus homarus) (Subani, 1981).

Pengusahaan lobster di Tabanan sudah berlangsung sejak lama. Daerah penangkapan lobster di kabupaten Tabanan meliputi perairan Kedungu, Batu Tampih, Yeh Gangga, Kelanting, Tegalmengkep, Soka, sampai ke perairan Selabih yang membentang di sepanjang pesisir dan perairan Tabanan mulai dari kecamatan Kediri, Tabanan, Selamadeg Timur, Selamadeg, dan Selamadeg Barat yang berbatasan dengan perairan kabupaten Jembrana. Kondisi perarian kabupaten Tabanan sangat mendukung sebagai habitat lobster, dimana karakteristik perairan di daerah ini adalah pasir dan karang.

Penelitian terdahulu di perairan ini menunjukkan bahwa tingkat pengusahaan lobster telah berada dalam keadaan lebih tangkap (Wahyuni et.al., 1993). Kajian aspek biologi lobster di perairan ini masih sangat terbatas, sementara itu informasi aspek biologi sangat berguna untuk dijadikan sebagai bahan dasar masukan untuk pengelolaan perikanan yang bertanggung jawab.

Penelitian ini bertujuan untuk mengetahui aspek biologi lobster pasir di perairan Tabanan yang meliputi nisbah kelamin, sebaran ukuran panjang karapas, sebaran matang kelamin, hubungan panjang dan berat, dan faktor kondisi relatif. Hasil yang diperoleh diharapkan dapat digunakan sebagai bahan masukan dalam pengelolaan perikanan lobster khususnya di perairan selatan Bali.

\section{BAHANDANMETODE}

Penelitian dilakukan selama bulan Maret - Desember 2013 melalui salah satu pengumpul lobster di Tabanan. Pemilihan lokasi ditentukan perdasarkan banyaknya produksi lobster yang didaratkan di lokasi tersebut. Alat tangkap lyang digunakan adalah bubu terbuat dari bambu. Pengamatan dan pengukuran parameter biologi dilakukan dengan cara acak terhadap contoh lobster pasir.

Ukuran panjang karapas yaitu bagian tengah daerah supra orbital sampai di bagian tengah posterior karapas (Sparre \& Venema, 1999). Pengukuran menggunakan jangka sorong (caliper veriner) dengan ketelitian 0,1 mm. Pengukuran berat individu menggunakan timbangan digital dengan ketelitian 1 gram. Penentuan jenis kelamin berdasarkan ciri mofologi lobster seperti yang dikemukakan oleh Prescott (1979) \& Chan (2000). Kematangan kelamin lobster didasarkan pada perkembangan warna telur pada bagian ventral lobster betina (Mac Diarmid \& Sainte-Marie, 2006).
Untuk mengetahui keseimbangan nisbah kelamin dilakukan pengujian chi-kuadrat pada tingkat kepercayaan 95\% (Steel \& Torrrie, 1993). Hubungan panjang karapas dengan berat individu mengikuti hukum kubik, bahwa berat individu sebagai pangkat tiga dari panjangnya mengikuti persamaan $\mathrm{W}=\mathrm{a} \mathrm{L}^{\mathrm{b}}$, dimana $\mathrm{W}$ adalah berat lobster (gram), L adalah panjang karapas ( $\mathrm{mm}$ ), a adalah konstanta dan b adalah nilai eksponensial (Bal \& Rao 1984; Effendi 2002). Selanjutnya untuk mengetahui sifat pertumbuhan lobster dilakukan uji-t terhadap koefisien pertumbuhan (nilai b) yang diperoleh dari persamaan regresi anatara panjang dengan berat lobster. Faktor kondisi (faktor kondisi relatif) dihitung berdasarkan persamaan $\mathrm{Kn}=\mathrm{W} / \mathrm{a} \mathrm{L}^{\mathrm{b}}$, dimana $\mathrm{W}$ adalah berat (gram), L adalah panjang karapas, a adalah intersep regresi dan b adalah koefisien regresi (LeCren, 1951; Effendi, 2002).

Pendugaan ukuran matang kelamin (size of maturity/ Lm) dan ukuran tertangkap (length at capture/Lc) dilakukan dengan pendekatan fungsi logistik dengan bantuan perangkat Sigma Plot versi 10.0. Ukuran matang kelamin dinyatakan dengan ukuran pada saat $50 \%$ lobster betina membawa telur (size at $50 \%$ ovigerous) dan ukuran tertangkap dalam ukuran pada saat $50 \%$ lobster tertangkap $\left(\mathrm{Lc}_{50 \%}\right)$.

\section{HASIL DAN BAHASAN \\ HASIL}

\section{Nisbah Kelamin dan Sebaran Panjang}

Pengumpulan data diperoleh sebanyak 3.786 ekor lobster pasir (Panulirus homarus) terdiri dari 1.665 ekor jantan dan 1.749 ekor betina. Keseimbangan kelamin jantan dan betina $1: 1,06$. Secara statistik rasio tersebut tidak menunjukkan beda nyata $\left(\mathrm{X}_{\text {hitung }}^{2}<\mathrm{X}_{\text {tabel }}^{2}\right.$ pada tingkat kepercayaan 95\%). Hal ini berarti bahwa nisbah kelamin lobster pasir di perairan ini berada dalam keadaan seimbang.

Kisaran panjang karapas lobster pada masing-masing pengamatan disajikan pada Tabel 1. Tampak bahwa ukuran terkecil lobster jantan dan betina diperoleh pada bulan Maret sedangkan ukuran terpanjang lobster jantan diperoleh pada bulan Juni dan lobster betina pada bulan Oktober. Ukuran maksimal panjang karapas lobster betina lebih panjang $0,84 \%$ dari pada lobster jantan. Berdasarkan uji-t pada tingkat kepercayaan $95 \%$ rata-rata panjang karapas lobster jantan dan betina tidak berbeda nyata. Lobster pasir yang ditangkap pada bulan OktoberDesember cenderung memiliki karapas yang lebih panjang dari pada waktu pengamatan lainnya.

Secara umum terdapat dua modus ukuran panjang karapas yaitu pada nilai tengah 47,5 mm dan 97,5 mm. Panjang karapas dominan tertangkap didapat pada nilai 
tengah 47,5 mm baik pada lobster jantan maupun betina, sedangkan pada modus panjang 97,5 mm jumlah lobster yang tertangkap lebih sedikit. Lobster jantan paling banyak tertangkap pada panjang karapas kurang dari $62,5 \mathrm{~mm}$, sebaliknya lobster betina pada ukuran panjang karapas lebih dari 62,5 mm (Gambar 1).

\section{Kematangan Kelamin}

Pengamatan kematangan kelamin lobster betina berdasarkan kematangan secara fungsional, ditandai dengan lobster betina yang mengerami telur pada kaki renangnya (egg bearing female). Lobster betina yang membawa telur diperoleh selama bulan-bulan pengamatan. Hal ini menunjukkan bahwa proses regenerasi terjadi sepanjang tahun. Persentase lobster betina yang membawa telur cenderung tinggi pada bulan JuniSeptember dan mencapai puncaknya pada bulan Oktober, sebaliknya cenderung rendah pada bulan Maret-Mei (Gambar 2).

\section{Hubungan Panjang dan Berat}

Hubungan panjang karapas dan berat menggambarkan sifat pertumbuhan lobster. Berdasarkan hasil analisa hubungan panjang berat diperoleh nilai koefisien pertumbuhan (nilai b) pada lobster jantan dan betina masing masing sebesar 2,769 dan 2,841. Persamaan hubungan panjang berat lobster jantan adalah $\mathrm{W}=0,0021$ $\mathrm{L}^{2,769}$ dan betina adalah $\mathrm{W}=0,0016 \mathrm{~L}^{2,841}$. Nilai $\mathrm{b}$ atau koefisien pertumbuhan telah diuji-t pada tingkat kepercayaan $95 \%$ untuk melihat sifat pertumbuhan apakah isometrik $(b=3)$ atau allometrik $(b \neq 3)$. Hasil uji menunjukkan bahwa koefiseien pertumbuhan pada lobster jantan dan betina tidak sama dengan tiga, berarti lobster jantan maupun betina memiliki sifat pertumbuhan allometrik negatif $(b<3)$. Hal yang sama juga diperoleh jika tidak dilakukan pemisahan antara lobster jantan dan betina (Tabel 2).

Tabel 1. Kisaran panjang karapas lobster pasir di perairan Tabanan, 2013

Table 1. Range of carapace length frequency of scalloped spiny lobster in Tabanan waters, 2013

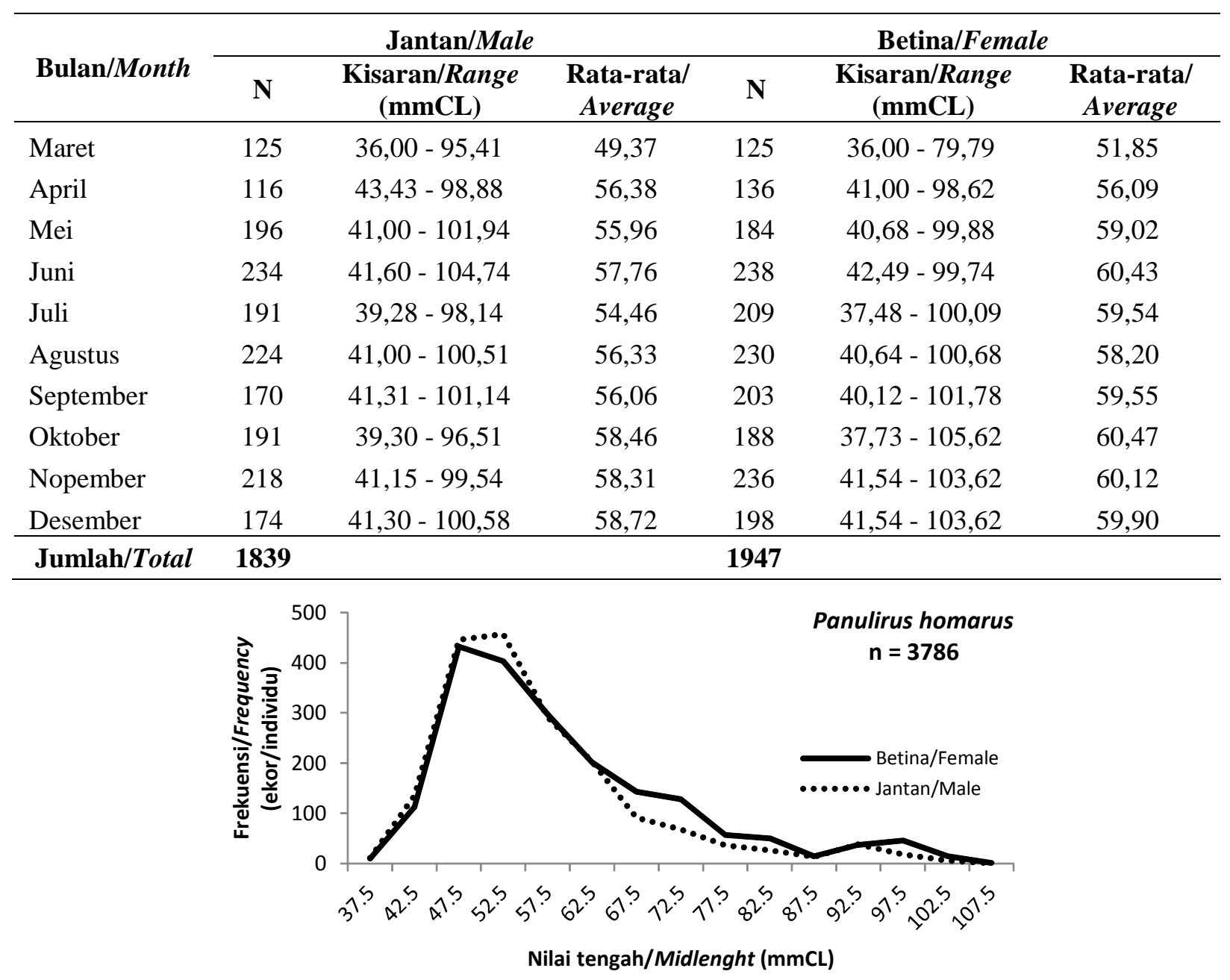

Gambar 1. Sebaran ukuran panjang karapas lobster pasir di perairan Tabanan, 2013.

Figure 1. Carapace length distribution of scalloped spiny lobster in Tabanan waters, 2013. 


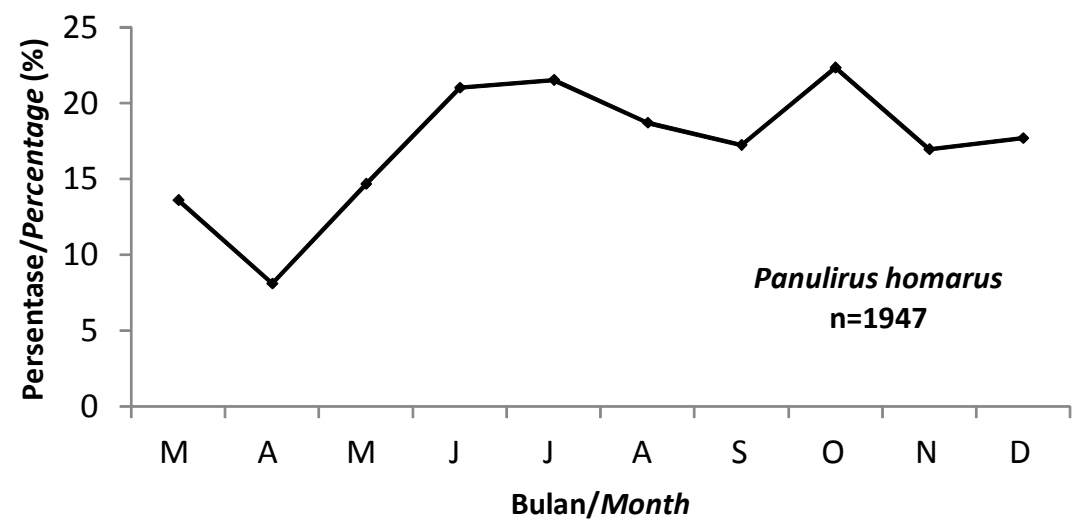

Gambar 2. Sebaran kematangan kelamin lobster pasir di perairan Tabanan, 2013.

Figure 2. Monthly maturity distribution of scalloped spiny lobster in Tabanan waters, 2013.

Tabel 2. Hasil analisa hubungan panjang karapas dan berat lobster pasir di perairan Tabanan

Table 2. Length-weight relationship analysis result of scalloped spiny lobster in Tabanan waters

\begin{tabular}{cccccccc}
\hline Jenis/Sex & $\begin{array}{c}\text { N (ekor/ } \\
\text { individu) }\end{array}$ & $\mathbf{a}$ & $\mathbf{b}$ & $\mathbf{R}^{\mathbf{2}}$ & $\begin{array}{c}\mathbf{t}_{\text {hitung/ }} \\
\mathbf{t}_{\text {test }}\end{array}$ & $\begin{array}{c}\mathbf{t}(\boldsymbol{\alpha}= \\
\mathbf{0 . 0 5})\end{array}$ & $\begin{array}{c}\text { Sifat pertumbuhan/ } \\
\text { Growth } \\
\text { characteristic }\end{array}$ \\
\hline Jantan/Male & 1839 & 0,0021 & 2,769 & 0.888 & 4,714 & 1,961 & Allometrik negatif \\
Betina/Female & 1947 & 0,0016 & 2,841 & 0,926 & 7,411 & 1,961 & Allometrik negatif \\
Gabungan/Both sexes & 3786 & 0,0018 & 2,811 & 0,910 & 8,309 & 1,961 & Allometrik negatif \\
\hline
\end{tabular}

\section{Faktor Kondisi Relatif}

Faktor kondisi relatif lobster pasir betina berkisar antara $0,937 \pm 0,156-1,179 \pm 0,080$ dan lobster jantan berkisar antara $0,966 \pm 0,206-1,107 \pm 0,089$. Faktor kondisi relatif tertinggi diperoleh pada bulan Maret dan terendah diperoleh pada bulan Juni, baik pada lobster jantan maupun betina (Gambar 3). Faktor kondisi relatif cenderung menurun seiring bertambah besarnya ukuran lobster. Penurunan nilai faktor kondisi relatif sangat drastis pada ukuran panjang karapas diatas 87,5 mm, kecenderungan ini terjadi pada kedua jenis kelamin lobster (Gambar 4).

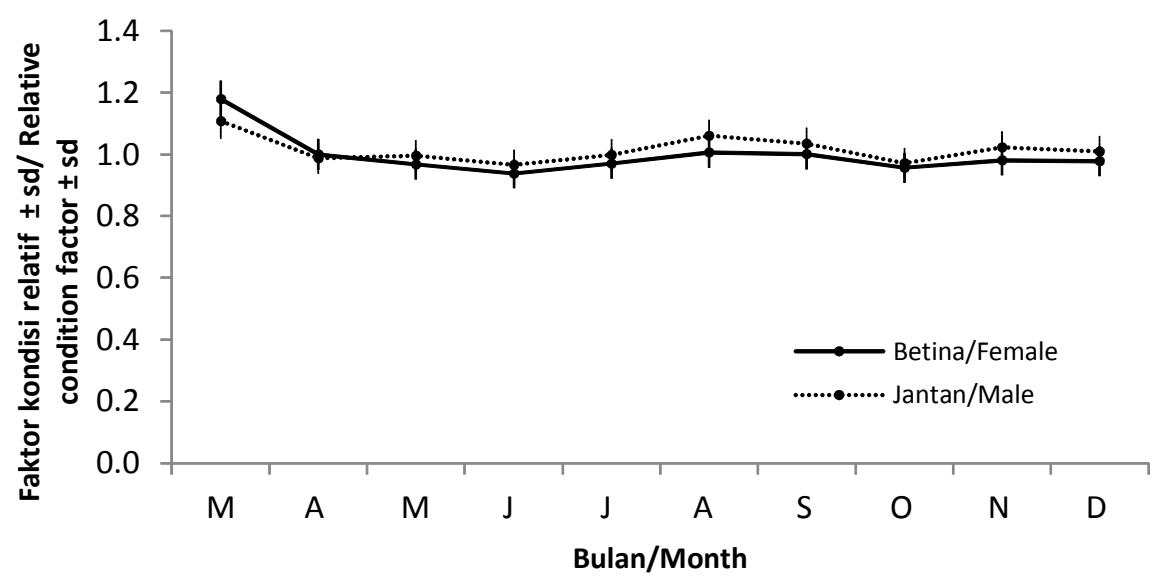

Gambar 3. Faktor kondisi relatif lobster pasir berdasarkan bulan pengamatan di perairan Tabanan, 2013.

Figure 3. Seasonal relative condition factor of scalloped spiny lobster in Tabanan waters, 2013. 


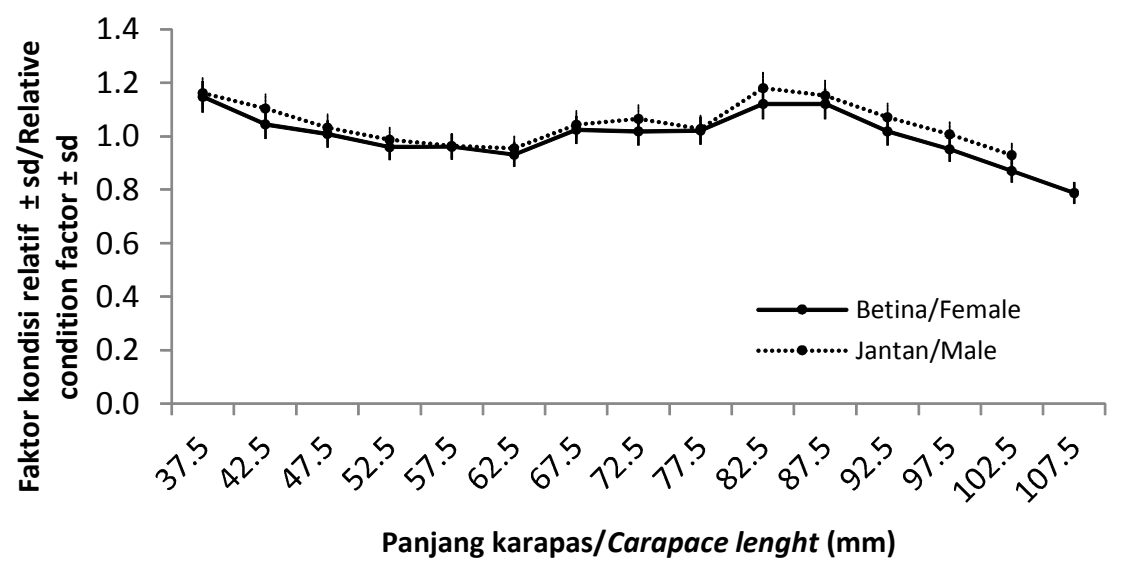

Gambar 4. Faktor kondisi relatif lobster pasir berdasarkan ukuran panjang karapas di perairan Tabanan, 2013.

Figure 4. Relative condition factor of scalloped spine lobster according to the carapace length in the Tabanan water, 2013.

\section{Ukuran Pertama Kali Tertangkap (Lc) dan Pertama Kali Matang Kelamin (Lm)}

Hasil analisa dengan kurva logistik terhadap ukuran lobster yang tertangkap (length at capture/Lc) dan ukuran mencapai kematangan kelamin (size on maturity) menunjukkan bahwa rata-rata ukuran lobster yang tertangkap (Lc) dengan bubu memiliki panjang karapas $52,7 \mathrm{~mm}$, sedangkan rata-rata ukuran matang kelamin (membawa telur) pada panjang karapas $68,52 \mathrm{~mm}$. Hal ini menunjukkan bahwa lobster di perairan Tabanan ini sudah lebih dulu tertangkap sebelum mencapai ukuran matang kelamin $(\mathrm{Lc}<\mathrm{Lm})$.

\section{BAHASAN}

Lobster pasir (Panulirus homarus) merupakan jenis lobster yang dominan tertangkap di perairan Tabanan. Berdasarkan pengamatan di lapangan lebih dari $90 \%$ lobster yang tertangkap di perairan ini merupakan jenis lobster pasir. Hasil penelitian Subani (1981), menunjukkan bahwa di pantai selatan Bali ditemukan 7 jenis lobster/ udang barong yaitu lobster pakistan (Panulirus polypagus), udang pantung/lobster pasir ( $P$. homarus), udang bunga/lobster batik ( $P$. longipes), udang belang/ lobster mutiara (P. ornatus), udang jaka/lobster batu ( $P$. penicillatus), $P$. leavicauda, dan udang cemara/lobster hijau bambu (P. versicolor) dan $\pm 90 \%$ merupakan lobster pasir. Hal ini menunjukkan bahwa dominansi jenis lobster di perairan ini tidak mengalami perubahan selama kurang lebih tiga dekade terakhir.

Penelitian aspek biologi lobster diperlukan untuk memperoleh informasi biologis yang dapat berguna sebagai bahan dasar untuk menyusun kebijakan pengelolaan perikanan lobster. Wahyuono et al. (1983) mengemukakan bahwa agar kelestarian populasi tetap terjaga idealnya nisbah kelamin ikan berada dalam keadaan seimbang atau jumlah betina lebih banyak. Nisabah kelamin digunakan untuk keperluan pengetahuan dasar dari biologi reproduksi (Holden \& Raitt, 1974) dan juga untuk melihat populasi suatu organisme dalam mempertahankan populasinya atau disebut juga sebagai indikator kemampuan suatu populasi untuk tetap bertahan melalui rekrutment (Ault et al., 1995 dalam Kamrani et al., 2010).

Nisbah kelamin lobster pasir pada penelitian ini berada dalam keadaan seimbang. Hasil ini sama dengan hasil penelitian terdahulu di perairan selatan Bali (Subani et al., 1983) dan Teluk Ekas-Lombok (Junaidi et al., 2010). Berbeda dengan hasil penelitian di perairan Aceh Barat (Suman \& Subani, 1993) yang memperoleh bahwa nisbah kelamin lobster pasir berada dalam keadaan tidak seimbang dimana lobster betina lebih mendominasi.

Dengan demikian diketahui bahwa kemampuan lobster pasir untuk mempertahankan populasi di perairan Tabanan masih baik. Perbedaan hasil penelitian ini dengan di perairan Aceh Barat diduga disebabkan oleh kondisi lingkungan perairan yang berbeda sehingga pertumbuhan lobster juga menjadi berbeda. Effendi (2002) menyatakan bahwa variasi nisbah kelamin dapat terjadi karena disebabkan oleh tiga faktor, yaitu perbedaan tingkah laku seks, kondisi lingkungan, dan lokasi penangkapan.

Rata-rata ukuran panjang karapas lobster pasir jantan dan betina cenderung sama, namun demikian ukuran maksimal lobster pasir betina sedikit lebih panjang $(0,84 \%)$ daripada jantan. Lobster jantan lebih banyak tertangkap pada ukuran panjang karapas dibawah $62,5 \mathrm{~mm}$ dan sebaliknya lobster betina lebih banyak tertangkap pada ukuran panjang karapas diatas $62,5 \mathrm{~mm}$. Secara keseluruhan, lobster yang pasir yang tertangkap di perairan ini didominasi oleh lobster muda dengan ukuran panjang karapas $47,5-52,5 \mathrm{~mm}$. 
Seperti telah diutarakan sebelumnya bahwa sebaran kematangan kelamin lobster didasarkan pada ciri fungsional yaitu ditandai dengan adanya telur yang dibawa/dierami lobster betina (egg bearing female). Hasil penelitian ini menunjukkan bahwa musim pemijahan cenderung tinggi pada bulan Juni-September dan mencapai puncaknya pada bulan Oktober. Hasil penelitian Suman et al. (1994) di perairan Pangandaran memperoleh bahwa puncak musim penambahan baru lobster pasir terjadi pada bulan Oktober. Hasil penelitian ini menunjukkan fenomena yang sama dengan di perairan Pangandaran.

Hasil analisa persamaan hubungan panjang dan berat menunjukkan bahwa pola pertumbuhan lobster pasir di perairan Tabanan adalah allometrik negatif $(b<3)$ baik pada jantan maupun betina (Tabel 2). Hal ini berarti bahwa pertumbuhan panjang karapas lebih cepat daripada pertambahan berat lobster. Penelitian hubungan panjang dan berat lobster pasir telah di lakukan di beberapa perairan seperti yang disajikan pada Tabel 3.

Tabel 3. Koefisien pertumbuhan (b) lobster pasir di beberapa lokasi perairan Indonesia

Table 3. Growth coefficient (b) of scalloped spiny lobster in some Indonesian waters

\begin{tabular}{cccc}
\hline $\begin{array}{c}\text { Lokasi/ } \\
\text { Location }\end{array}$ & b & $\begin{array}{c}\text { Pola Pertumbuhan/ } \\
\text { Growth Pattern }\end{array}$ & $\begin{array}{c}\text { Referensi/ } \\
\text { References }\end{array}$ \\
\hline Selatan Bali & $3,0244^{\mathrm{g}}$ & Allometrik positif & Subani et al., 1983 \\
Aceh Barat & $2,4322^{\mathrm{g}}$ & Allometrik negatif & Suman \& Subani, 1993 \\
Pangandaran & $2,3170^{\mathrm{g}}$ & Allometrik negatif & Suman et al., 1994 \\
Teluk Ekas, Lombok & - & Allometrik negatif & Junaidi et al., 2010 \\
Yogyakarta & $2,7880^{\mathrm{g}}$ & Allometrik negatif & Aisyah \& Triharyuni, 2010 \\
Yogyakarta & $2,8280^{\mathrm{b}}$ & Allometrik negatif & Hargiyatno et al., 2013 \\
Yogyakarta & $2,7540^{\mathrm{j}}$ & Allometrik negatif & Hargiyatno et al., 2013 \\
\hline
\end{tabular}

Keterangan/Remarks $: \mathrm{g}=$ gabungan/both sexes $; \mathrm{b}=$ betina/female $; \mathrm{j}=\mathrm{jantan} /$ male

Hasil penelitian di perairan-perairan tersebut juga menunjukkan pola pertumbuhan yang sama dengan yang diperoleh pada penelitian ini yaitu allometrik negatif kecuali di perairan selatan Bali yang memiliki pola pertumbuhan allometrik positif. Namun demikian nilai b atau koefisien pertumbuhan yang diperoleh berbeda dari masing-masing lokasi perairan. Perbedaan koefisien pertumbuhan ini disebabkan oleh faktor biologis seperti perkembangan gonad, kebiasaan makan, fase pertumbuhan dan jenis kelamin (Froose, 2006; Tarkan et al., 2006) dan faktor ekologis, seperti musim, kualitas air, suhu, salinitas, derjat keasaman $(\mathrm{pH})$ serta posisi geografis dan teknik pengambilan contoh (Zargar et al., 2012).

Faktor kondisi relatif lobster jantan cenderung lebih tinggi daripada betina, namun demikian tidak diperoleh perbedaan yang signifikan diantara keduanya. Faktor kondisi terendah diperoleh pada bulan Juni dan tertinggi pada bulan Maret. Faktor kondisi juga semakin menurun seiring dengan pertambahan ukuran panjang karapas atau semakin bertambahnya umur lobster pasir. Hasil penelitian Hargiyanto et al. (2013) di perairan selatan Yogyakarta menunjukkan bahwa ada indikasi faktor kondisi semakin menurun seiring bertambahnya panjang karapas. Hasil penelitian ini semakin menjelaskan dan menegaskan indikasi tersebut.
Hasil penelitian ini juga menunjukkan bahwa ada keterkaitan antara faktor kondisi dengan sebaran kematangan kelamin lobster secara fungsional/membawa telur. Ditemukan bahwa pada periode musim dimana persentase lobster yang membawa telur banyak diperoleh faktor kondisi relatifnya cenderung rendah dan sebaliknya pada saat persentase lobster yang membawa telur rendah maka faktor kondisi relatifnya lebih tinggi. Hal ini diduga disebabkan karena pada pemijahan kondisi lobster khususnya betina cenderung menurun karena membutuhkan banyak energi untuk proses pemijahan. Secara umum faktor kondisi dihitung untuk menilai kesehatan ikan, produktivitas dan kondisi biologi dari populasi ikan (Blackwell et al., 2000). Selanjutnya faktor kondisi juga mencerminkan karakteristik morfologi tubuh, kandungan lipid, dan tingkat pertumbuhan (Froese, 2006). Faktor kondisi juga dapat digunakan untuk menunjukkan perubahan kondisi ikan sepanjang tahun dan secara tidak langsung dapat menjadi penanda perubahan lingkungan (Raharjo et al., 2011).

Hasil penelitian ini menunjukkan bahwa ukuran rerata panjang karapas lobster yang tertangkap lebih kecil daripada ukuran lobster pada saat matang kelamin. Hal ini mengindikasikan bahwa kondisi lobster pasir di perairan ini sudah mulai terancam dikarenakan lobster-lobster tersebut sudah terlebih dahulu tertangkap sebelum 
melakukan proses reproduksi. Kondisi penangkapan yang baik untuk menunjang proses rekrutmen adalah ketika ukuran panjang individu yang ditangkap sama dengan ukuran pada saat mencapai kematangan kelamin (SoM). Ukuran panjang tangkapan yang lebih rendah dibandingkan ukuran matang kelamin akan mengakibatkan penurunan stok sumberdaya akibat terhambatnya proses rekrutmen (Henriques, 1999 dalam Pinheiro \& LinsOliveira, 2006). Hasil penelitian ini juga menunjukkan aktivitas penangkapan sudah mengakibatkan terancamnya kelestarian sumberdaya yang ada. Oleh karena itu diperlukan upaya pengelolaan perikanan lobster yang berkelanjutan melalui penetapan ukuran minimun yang boleh ditangkap. Dari hasil penelitian ini, disarankan ukuran minimum lobster yang boleh ditangkap diatas ukuran mencapai kematangan kelamin yaitu pada panjang karapas $>68,52 \mathrm{~mm}$.

\section{KESIMPULAN}

Lobster pasir (Panulirus homarus) merupakan jenis yang dominan ditangkap di perairan Tabanan. Nisbah kelamin lobster pasir berada pada keadaan seimbang dan yang dominan tertangkap cenderung masih berusia muda. Puncak musim pemijahan terjadi pada bulan Oktober. Pola pertumbuhan lobster pasir adalah allometrik negatif. Faktor kondisi relatif rendah pada pada saat musim pemijahan dan semakin menurun seiring dengan bertambah panjangnya ukuran karapas lobster. Rata-rata ukuran lobster yang tertangkap lebih kecil dari ukuran matang kelamin. Oleh karena itu disarankan untuk menetapkan ukuran minimum yang boleh ditangkap yaitu pada panjang karapas lebih dari 68,52 $\mathrm{mm}$.

\section{PERSANTUNAN}

Tulisan ini merupakan kontribusi dari kegiatan Penelitian Status dan Optimasi Pemanfaatan Sumberdaya Udang Penaeid dan Krustasea Lain dalam Mendukung Industrialisasi Perikanan di Samudera Hindia Barat Sumatera (WPP 572), Samudera Hindia Selatan Jawa dan Nusa Tenggara (WPP 573) serta di Teluk Cendrawasih dan Samudera Pasifik (WPP 717) di Balai Penelitian Perikanan Laut T.A. 2013.

\section{DAFTAR PUSTAKA}

Aisyah \& S. Triharyuni. 2010. Production, size distribution, and length-weight relationship of lobster landed in the south coast of Yogyakarta, Indonesia. Ind. Fish. Res.J. 16 (1): 15 - 24.

Bal, D. V. \& K. V. Rao. 1984. Marine Fisheries. Tata Mc. Graw-hill Publishing Company Limited. New Delhi: 5-24.
Blackweel, B. G., M. L. Brown \& D. W. Willis. 2000. Relative weight (Wr) status and current use in fisheries assessment and management. Reviews in Fisheries Science, 8: 1-44.

Chan, T. Y. 2000. Lobster. In Living Marine Resources of the Western Central Pacific. Vol. 2. Cephalopods, crustacean, holothurians, and sharks. FAO Species Identification Guide for Fishery Purposes. FAO-UN, Norwegian Agency for International Development: $974-1.043$.

Effendie, M. I. 2002. Biologi Perikanan. Yayasan Pusaka Nusantara. Yogyakarta. $163 \mathrm{hlm}$.

Froese, R. 2006. Cube law, condition factor and weightlength relationships: history, meta-analysis and recommendations. Journal of Applied Ichthyology. $22(4): 241-253$.

Holden, M. J. \& D. F. S. Raitt., 1974. Manual of Fisheries Science. FAO. Rome. Part 2-Methods of Resources Investigation and their Application: 135.

Junaidi, M., N. Cokrowati \& Z. Abidin. 2010. Aspek reproduksi lobster (Panulirus spp.) di perairan Teluk Ekas Pulau Lombok. Jurnal Kelautan. 3 (1): $29-36$.

Kamrani E, A. N. Sabili, \& M. Yahyavi. 2010. Stock assessment and reproductive biology of the blue swimming crab, Portunus pelagicus in Bandar Abbas Coastal Waters, Norther Persian Gulf. Journal of The Persian Gulf. Marine Science. 1(2): 11-22.

Le Cren ED. 1951. The length-weight relationship and seasonal cycle in gonad weight and conditions in the perch Perca fluviatilis. J. Animal Ecol. 20: 201219.

MacDiarmid, A. B. \& B. Sainte-Marie. 2006. Reproduction. In B.F. Phillips (Ed.) Lobsters: Biology, Management, Aquaculture and Fisheries. Blackwell Publishers: 45-77.

Prescott, J. 1979. Report on the South Pacific commission lobster project in Solomon Island, Noumea, South Pacific Commission. 20p.

Raharjo, M. F., S. Djadja, S. Ridwan \& A. Johannes. 2011. Iktiologi. Lubuk Agung Bandung. 396p.

Sparre, P. \& S. Venema. 1999. Introduction to Tropical Fish Stock Assesment. (IntroduksiPengkajian 
Stok Ikan Tropis, alih bahasa: Pusat Penelitian dan Pengembangan Perikanan). Buku 1: Manual. Badan Penelitian dan Pengembangan Perikanan. Jakarta. $438 \mathrm{pp}$.

Steel, R. D. G. \& J. H. Torrie. 1993. Prinsip dan Prosedur Statistika, Suatu Pendekatan Biometrik. Terjemahan B. Sumantri. Jakarta: PT. Gramedia Pustaka Utama.

Subani, W. 1981. Penelitian lingkungan hidup udang barong (spiny lobster), perikanan dan pelestarian sumberdaya di pantai selatan Bali. Bull. Pen. Perikanan, 1 (3): 361 - 386

Subani, W., B. Sadhotomo \& K. Suwirya. 1983. Penelitian tentang pertumbuhan dan beberapa parameter biologi udang panting (Panulirus homarus) di perairan pantai selatan Bali. Laporan Penelitian Perikanan Laut: 57 - 65.

Suman, A. \& W. Subani. 1993. Pengusahaan sumberdaya udang karang di perairan Aceh Barat. Jurnal Penelitian Perikanan Laut, (81): 84 - 90

Suman, A., W. Subani \& P. Prahoro. 1994. Beberapa parameter biologi udang pantung (Panulirus homarus) di perairan Pangandaran Jawa Barat. Jurnal Penelitian Perikanan Laut, (85): 1 - 8.

Tarkan, A. S., O. Gaygusuz, P. Acipinar, C. Gursoy \& M. Ozulug. 2006. Leight-weight relationships of fishes from the Marmara region (NW-Turkey). Journal of Applied Ichthyology, 22 (4): 271-273.

Wahyuni, I. S., S. T. Hartati, \& W. Subani. 1994. Perikanan udang karang (spiny lobster) di perairan kabupaten Tabanan, Bali. Jurnal Pen. Perikanan Laut, 87: 84-90.

Wahyuono, H., S. Budihardjo, Wudianto, \& R. Rustam. 1983. Pengamatan parameter biologi beberapa jenis ikan demersal di perairan Selat Malaka, Sumatera Utara. Laporan Penelitian Perikanan Laut, (26): 29-48.

Zargar, U. R., A. R. Yousuf, B. Mushtaq \& D. Jan. 2012. Length-weight relationships og the crucian carp, Carrassius carrassius in relation to water quality, sex and season in some lenthic water bodies of Kashmir Himalayas. Turkeys Journal of Fisheries and Aquatic Sciences, 12: 685-691. 